\title{
Proposal of a Geographic Information System for modeling zoonotic fasciolosis transmission in the Andes
}

\author{
MÀRIUS V. FUENTES *
}

\begin{abstract}
The present study describes the basis for the development of a Geographic Information System (GIS) for conducting an epidemiological analysis of human and animal fasciolosis in the Andes. The methodology proposes the use of various data bases - those derived from epidemiological mutidisciplinary studies and environmental data derived from terrestrial stations and remote sensing.

Key words: Fasciola hepatica, fasciolosis transmission, Andes, geographic information system, model.
\end{abstract}

\section{INTRODUCTION}

Over the last decade, the importance of human and animal fasciolosis in various south American countries has been emphasized in the scientific literature ${ }^{1-5}$; indeed, human infection by Fasciola hepatica has recently been declared an important worldwide health problem ${ }^{6,7}$. Of the countries located on the slopes of the Andes, Peru, Bolivia and Chile are the most severely affected by this liver fasciolosis ${ }^{2}$ - though areas of Ecuador, Colombia and Venezuela are also affected. The Northern Altiplano, between Bolivia and Peru, is considered to be a hyperendemic zone for both humans and animals while the central regions of Chile are hyperendemic in terms of domestic cattle $^{8-10}$.

The different climatic and altitudinal conditions found in these areas underscore the need for a detailed study of each of these individual endemic areas.
The narrow relationship between the parasite and the climate has been intensely studied, mainly in some parasitic diseases of marked importance for humans and animals. This has, in turn, made it possible to - sometimes quite accurately predict the risk periods for humans and animals ${ }^{11,12}$ as well as the development of predictive models concerning the development and evolution of parasitic populations ${ }^{13}$. For many years, these predictive models were constructed using vast historical databases containing information originating from terrestrial stations ${ }^{13}$.

However, it was some 30 years ago that Cline $^{14}$ suggested the use of air pictures and other remote sensing sources in epidemic studies in such a way that a database could be digitized obtaining some excellent references on storms and space. Consequently, this author proposed the creation of Geographic Information Systems (GIS) for the application in epidemiological studies of various human and animals diseases. However,

\footnotetext{
* Departament de Parasitologia, Facultat de Farmàcia, Universitat de València, Av. Vicent Andrés Estellés s/n, 46100 Burjassot-València, Spain.

Tel: +34-96-3544298; Fax: + 34-96-3544769; E-mail address: mario.v.fuentes@uv.es
} 
and in spite of Cline's call for action, it was only a decade ago, that the public health community began to realize the potential of the applications offered by GIS and remote sensing technology.

\section{PRESENTATION OF THE PROPOSAL}

In the last decade, a number of studies have demonstrated the usefulness of remote sensing data in furthering epidemiological knowledge of the various diseases transmitted by vectors, mainly arthropods ${ }^{15-17}$, such as malaria ${ }^{18-20}$, leishmaniosis ${ }^{21,22}$, trypanosomosis ${ }^{23}$, Chagas disease $^{24}$, alveolar echinococcosis ${ }^{25}$, hookworms ${ }^{26}$ or lymphatic filariosis ${ }^{27}$. Likewise, J. B. Malone and co-workers ${ }^{28,29}$ have shown this methodology to be valid in the epidemiological study of snailborne parasitic diseases, including schistosomosis and fasciolosis.

In the case of fasciolosis, studies carried out in East Africa, successfully used climatic variables and the normalized difference vegetation index (NDVI), which shows the general response of vegetation to rainfall, derived from the analysis of images obtained by earth observing satellites ${ }^{29}$.
In this context, and as part of a multidisciplinary project on human and animal fasciolosis in various Andean countries, the present proposal describes the basis for the development of Geographic Information Systems (GIS) for conducting an epidemiological analysis of human and animal fasciolosis in the Andes.

Following the recommendations of the GNOSIS (GIS Network On Snail-borne Infections with special reference to Schistosomiasis) research group ${ }^{30}$, all GIS are based on the use of a database (epidemiological, environmental, remote sensing type, etc) which, together with the application of specialized software, is reflected in cartographic form with subsequent analysis. This approach allows the development of an epidemiological model of the disease in the area under study. It would hardly be possible to implement GIS without contribution of the epidemiological data obtained by the various teams that constitute the present multidisciplinary project.

A parasitological database has been developed containing information on: a) the forms of the parasites present in the environment (eggs and

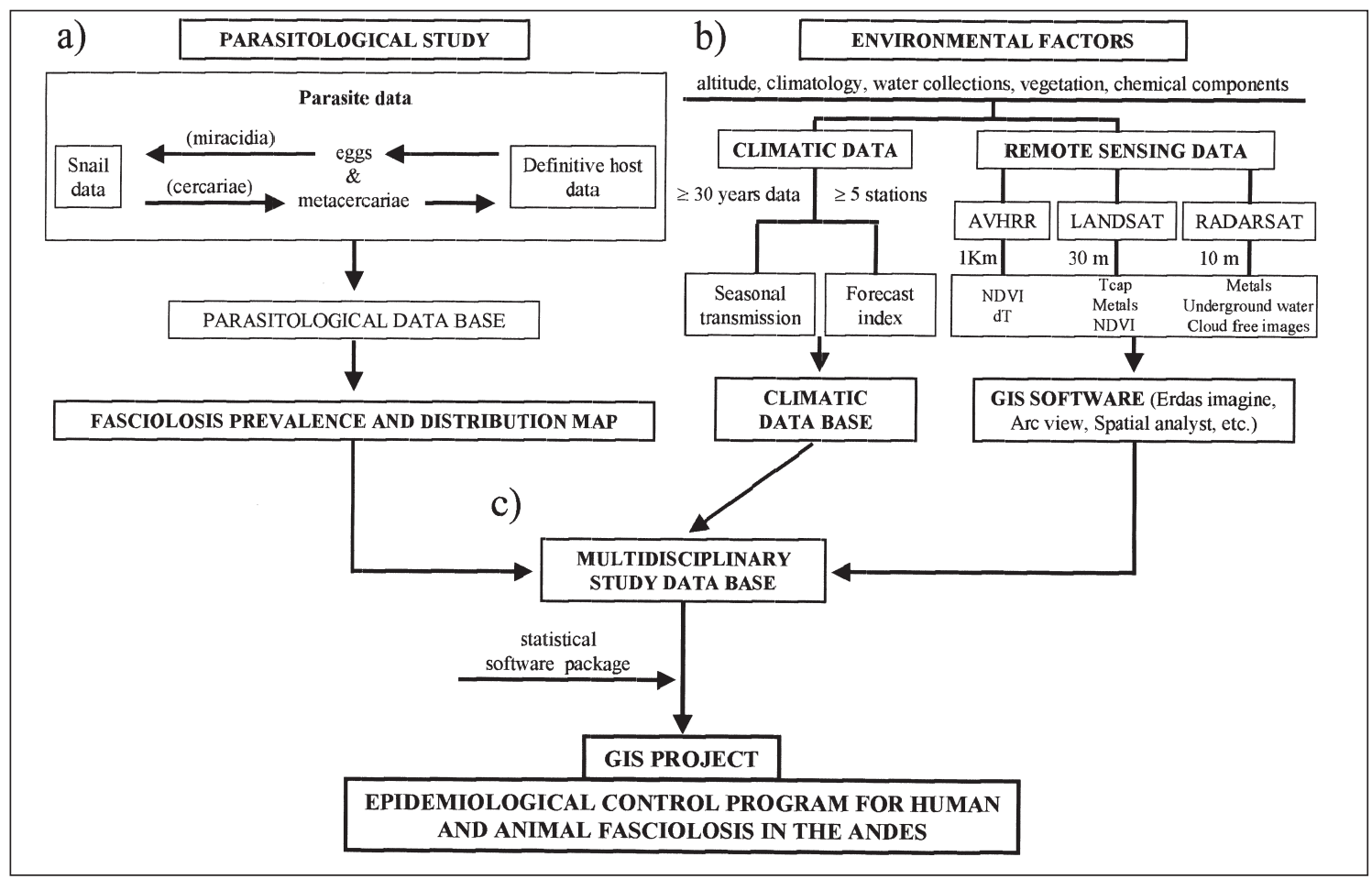

Figure 1. Diagram presenting the GIS model for epidemiological control program for zoonotic fasciolosis in the Andes. 
metacercariae); b) the intermediate hosts mollusks involved; and c) the definitive hosts (i.e., humans, cattle and other possible reservoirs). The collection and processing of the data from the studies of the parasite forms and intermediate and definitive hosts facilitates the development of the first database and the corresponding «Fasciolosis Prevalence and Distribution Map» (Figure 1a).

At the same time, an analysis is made of the most important environmental factors (Figure 1b) that may most directly influence the prevalence and transmission of this fasciolosis. These factors are fundamentally grouped into climatic and remote sensing parameters which are obtained from terrestrial stations and orbiting satellite images.

Based on the size of the area under study, a minimum of 5 climatic stations are proposed for collecting the annual means corresponding to a period of no less than 30 years to establish the possibility of seasonal transmissions and permit the application of prediction indices. In terms of climate, an analysis must be made of all the factors available from each of the meteorological sampling stations with monthly recordings. Based on these climatic data, the different climadiagrams corresponding to each station are elaborated and used to extrapolate certain general climatic features of the zone that may be of epidemiological interest, e.g. delimitation of the wet and dry seasons, the period of permanent frost, and the mean and extreme temperatures.

The calculation of climatic indices for the prediction of fasciolosis - specifically, the $\ll \mathrm{Mt}$ Index» and «Water-Budget Based Index»- allows us to establish the possibility of parasite transmission in the area of influence of each climatological station, and the possible seasonal variations in the course of the year. This predictions might be made using the above mentioned indices or their modified versions specially adapted to high altitude areas, e.g. the Andean mountain range, as proposed by Fuentes and co-workers ${ }^{31}$.

The remote sensing data are analyzed using specialized software to yield a series of parameters (i.e., NDVI; dT -diurnal temperature difference; Tcap -tasseled cap classification; metals; water; etc.) based on the type of satellite employed and the corresponding visual resolution performance (i.e., AVHRR images, $1.1 \mathrm{~km}$; Landsat images, 30-120 m; Spot images, 10-20 m; Radarsat images, $10 \mathrm{~m}$; etc).

The GIS project takes into account various databases corresponding to the multidisciplinary study, climatology and remote sensing information - using an appropriate and specialized software package - and, thus, contributes to the development of an «Epidemiological Program for the Control of Human and Animal Fasciolosis in the Andes» (Figure 1c).

The first part of this GIS project has been conducted on a regional scale in central Chile, based on the application of climatic and remote sensing data ${ }^{32}$.

A similar study has been carried out on a local scale in the Bolivian Northern Altiplano, with the aim of validating the results obtained, based on: a) the additional application of climatic data and prediction indices for human and animal fasciolosis ${ }^{31}$; b) an NDVI study of 36 AVHRR dekade (10-day) images corresponding to the period between May 1992 and April 1993 ${ }^{33}$.

The analysis of the results using the appropriate software has made it possible to develop regional and local scale fasciolosis risk maps for these hyperendemic zones - with specification of the different regions or localities presenting known prevalences, in correlation to transmission risk (i.e., no risk, low risk, moderate risk, and high risk).

In conclusion, the methodology presented is proposed to be valid for developing epidemiological models capable of precisely delimiting both the risk factors involved in transmission and the zones of greatest risk in relation to this important parasitic disease in low-per-capitaincome nations.

\section{RESUMEN}

El presente estudio describe la base para el desarrollo de un Sistema de Información Geográfica (SIG) para dirigir un análisis epidemiológico de la fascioliosis humana y animal en los Andes. La metodología propone el uso de varias bases de datos - derivadas de estudios epidemiológicos multidisciplinarios y de datos medioambientales derivados de estaciones terrestres y de satélites.

\section{REFERENCES}

1.- CHEN M G, MOTT K E. Progress in assessment of 
morbidity due to Fasciola hepatica infection: a review of recent literature. Trop Dis Bull 1990; 87: R1-R38.

2.- ALCAÍNO H. Epidemiology of fascioliasis in Chile. In: Basic Research in Helminthiasis. Edited by Ehrlich R, Nieto A y Yarzábal L. Ediciones Logos, Montevideo, Uruguay, $1990 \mathrm{p} \mathrm{11-30.}$

3.- ESTEBAN J G, BARGUES M D, MAS-COMA S. Geographical distribution, diagnosis and treatment of human fascioliasis: A review. Res Rev Parasitol 1998; 58: 13-42.

4.- MAS-COMA S, BARGUES MD, ESTEBAN JG. Human Fasciolosis. In JP Dalton, Fasciolosis, CAB International Publishing, Wallingford, 1999, p. 41134.

5.- SERRA-FREIRE N M da, BORDIN E L, LESSA C S S et al. Reinvestigacao sobre a distribuicao da Fasciola hepatica no Brasil. A Hora Veterinària 1995; ed extra 1: 19-21.

6.- MAS-COMA S, ESTEBAN JG, BARGUES M D. Epidemiology of human fascioliasis: a review and proposed new classification. Bull World Health Org 1999; 77: 340-6.

7.- MAS-COMA S, BARGUES M D, VALERO M A et al. Adaptation capacities of Fasciola hepatica and their relationsships with human fascioliasis: from below sea level up to the very high altitude. In Combes, J Jourdane, Taxonomie, écologie et evolution des métazoaires parasites. Taxonomy, ecology and evolution of metazoan parasites. (Livre homage à Louiis Euzet). Tome II, PUP, Perpignan, 2003, p 81-123.

8.- KNOBLOCK J, DELGADO E, ALVAREZ O. Human fascioliasis in Cajamarca, Perú I Diagnostic methods and treatment with praziquantel. Trop Med Parasitol 1985; 36: 88-90.

9.- APT W, AGUILERA X, ALCAÍNO $\mathrm{H}$ et al. Prevalencia de la fascioliasis en humanos, caballos, cerdos y conejos silvestres en tres Provincias de Chile. Bol Of Sanit Panam 1993; 115: 405-14.

10.- ALCAÍNO H, VEGA F, GORMAN T. Epidemiología de la fasciolasis hepática en la VII Región de Chile. Parasitol al Día 1993; 17: 99-106.

11.- ACOSTA D. Epidemiología y control de Fasciola hepatica en el Uruguay In: Nari A y Fiel C. Enfermedades Parasitarias de importancia económica en bovinos. Editorial Hemisferio Sur, Montevideo. 1994; 233-56.

12.- OLAECHEA F V. Fasciola hepatica y Paramphistomum Epidemiología y control de Fasciola hepatica In Nari A .y, Fiel. C. Editorial Hemisferio Sur, Montevideo 1989; 213-32.

13.- ALCAÍNO H. Predicción de las ionfestaciones por distomatosis en los animales de la VII, VIII y IX Regiones de Chile. Bol Epizoot. SAG Chile 1992; 3: 35-52.

14.- CLINE B L. New eyes for epidemiologists: aerial photography and other remote sensing techniques. Am J Epidemiol 1970; 92: 85-9.

15.- HUGH-JONES M. Applications of remote sensing to the identification of the habitats of parasites and disease vectors. Parasitol Today 1989; 5: 244-51.

16.- WASHINO R K, WOOD B L. Application of remote sensing to arthropod vector surveillance and control. Am J Trop Med Hyg 1994; 50 (Suppl): 134-44.
17.- HAY S I, RANDOLPHB S E, ROGERS D J (eds). Remote sensing and geographical information systems in epidemiology. Adv Parasitol 47. London: A Press; 2000.

18.- THOMSON M C, CONNOR S J, MILLIGAN P J M et al. The ecology of malaria as seen from Earthobservation satellites. Ann Trop Med Parasitol 1996; 90: 243-64.

19.- ROGERS D J, RANDOLPH S E, SNOW R W et al. Satellite imagery in the study and forecast of malaria. Nature 2002; 415: 710-5.

20.- HAY S, RENSHAW M, OCHOLA S A et al. Performance of forecasting, warming and detection of malaria epidemics in the highlands of western Kenya. Trends Parasitol 2003; 19: 394-9.

21.- THOMPSON R A, WELLINGTON DE OLIVEIRA LIMA J, MAGUIRE J H et al. Climatic and demographic determinants of American visceral leishmaniasis in northeastern Brazil using remote sensing technology for environmental categorization of rain and region influences on leishmaniasis. Am J Trop Med Hyg 2002; 67: 648-55.

22.- ELNAIEM D A, SCHORSCHER J, BENDALL A et al. Risk mapping of visceral leishmaniasis: the role of local variation in rainfall and altitude on the presence and incidence of kala-azar in eastern Sudan. Am J Trop Med Hyg 2003; 68: 10-7.

23.- HENDRICKX G, NAPALA A, SLINGENBERGH J H W et al. The spatial pattern of trypanosomosis prevalence predicted with the aid of satellite imagery. Parasitology 2000; 120: 121-34.

24.- TOWNSEND PETERSON A, SÁNCHEZ-CORDERO $\mathrm{V}$, BEARD C B et al. Ecologic niche modelling and potential reservoirs for Chagas disease, Mexico. Emerg Infect Dis 2002; 8: 662-7.

25.- STAUBACH C, THULKE H H, TACKMANN K et al. Geographic information system-aided analaysis of factors associated with the spatial distribution of Echinococcus multilocularis infections of foxes. Am J Trop Med Hyg 2001; 65: 943-8.

26.- MABASO M L H, APPLETON C C, HUGHES J C et al. The effect of soil type and climate on hookworm (Necator americanus) distribution in KwaZulu-Natal, South Africa. Trop Med Int Health 2003; 8: 722-7.

27.- LINDSAY S W, THOMAS C J. Mapping and estimating the population at risk from lymphatic filariasis in Africa. Trans R Soc Trop Med Hyg 2000; 94: 37-45.

28.- MALONE J B, ABDEL-RAHMAN M S, EL BAHY M $M$ et al. Geographic information systems and the distribution of Schistosoma mansoni in the Nile Delta. Parasitol Today 1997; 13: 112-9.

29.- MALONE J B, GOMMES R, HANSEN J et al. A geographic information system on the potential distribution and abundance of Fasciola hepatica and $F$. gigantica in east Africa based on Food and Agriculture Organization databases. Vet Parasitol 1998; 78: 87-101.

30.- MALONE J B, BERGQUIST N R, HUH O K et al. A global network for the control of snail-borne disease using satellite surveillance and geographic information systems. Acta Trop 2001; 79: 7-12.

31.- FUENTES M V, VALERO M A, BARGUES M D et al. Analysis of climatic data and forecast indices for human 
fascioliasis at very high altitude. Ann Trop Med Parasitol 1999; 93: 835-50.

32.- FUENTES M V, MALONE J B. Development of a forecast system for fasciolosis in Central Chile using remote sensing and climatic data in a geographic information system . Res Rev Parasitol 2000; 59: 129 34.

33.- FUENTES M V, MALONE J B, MAS-COMA. Validation of a mapping and prediction model for human fasciolosis transmission in Andean very high altitude endemic areas using remote sensing data. Acta Trop 2001; 79: 87-95.

Acknowledgements: This work was supported by funding from a Project (Contract No. TS3-CT94-0294) of the STD Program of the Commission of the European Communities
(DG XII: Science, Research and Development), Brussels, EU; two Projects of the Program of Scientific Cooperation with Latin America, Instituto de Cooperación Iberoamericana, Agencia Española de Cooperación Internacional (I.C.I.-A.E.C.I.), Madrid, Spain; Project PDP B2/181/125 of the WHO of Geneva, Switzerland; DGICYT Projects No. UE96-0001 and PM97-0099 of the Spanish Ministry of Education and Culture, Madrid, Spain; Project $\mathrm{N}^{\circ}$. BOS2002-01978 of the Spanish Ministry of Science and Technology, Madrid, Spain; Project No. 3006 of the Dirección General de Cooperación para el Desarrollo, Presidencia de Gobierno de la Generalitat Valenciana, Valencia, Spain; and the Red de Investigación de Centros de Enfermedades Tropicales - RICET (Project No . C03/04). A part of this work was supported by a Grant from the University of Valencia (Spain) awarded to the author for a sabbatical study at the Louisiana State University.

\section{ANUNCIO}

PARASITOLOGIA LATINOAMERICANA EN INTERNET

Información sobre Parasitología Latinoamericana y su versión electrónica se puede ahora encontrar en Internet. Dirección: www.scielo.cl 